\title{
IPTEKS PENYUSUNAN APBD PROVINSI SULAWESI UTARA
}

\author{
Nofriyanto Triyono ${ }^{1}$, Anneke Wangkar ${ }^{2}$ \\ ${ }^{1,2}$ Jurusan Akuntansi, Fakultas Ekonomi dan Bisnis Universitas Sam Ratulangi, Jl. Kampus Bahu, Manado, \\ 95115, Indonesia
}

Email : nofriyanto.triono@gmail.com

\begin{abstract}
The budget is prepared based on programs and activities that have been planned for a period of one year. For this reason, the Government through the Regional Head made a KUA draft which contained: (1) Revenue Policy, (2) Shopping Policy, (3) Financing Policy. In determining the KUA-PPAS budget allocation, regional financial management uses the money follow program priority approach, which is only to make priority programs that want to be done so that the budget can run efficiently. The general policy of the 2018 North Sulawesi provincial government budget is prepared by taking into account the regional macroeconomic aspects. The government continues to boost economic growth through regional taxes and levies to build a better North Sulawesi.
\end{abstract}

Keywords: revenue, expenditure, financing policy

\section{PENDAHULUAN}

Penganggaran dibutuhkan untuk pelaksanaan pembangunan nasional dan untuk melaksanakannya pemerintah perlu membuat suatu perencanaan yang matang dan ditinjau dari berbagai aspek. Menurut PP Nomor 17 Tahun 2017 Perencanaan dan penganggaran disusun berdasarkan tema, sasaran, arah kebijakan serta prioritas pembangunan. Untuk mencapai tujuan dari perencanaan tersebut maka diperlukan anggaran. Pemerintah membagi dua jenis anggaran yang terdiri dari anggaran negara dan anggaran daerah yang kemudian dikenal dengan APBN dan APBD. Kebijakan Perencanaan dan penganggaran ini disusun berdasarkan pendekatan kinerja.

Berdasarkan penentuan alokasi anggaran pemerintah menggunakan pendekatan money follow program priority yang baru diterapkan di Indonesia pada tahun 2017 fokus utama dari pendekatan ini untuk mendanai dan melaksanakan program-program yang menjadi prioritas utama. Untuk itu pemerintah daerah melalui BAPPEDA menyusun rancangan kebijakan umum anggran tujuannya untuk mengetahui target apa yang harus dicapai dalam periode satu tahun. Dalam penyelenggaraan pembangunan pemerintah mengalami keterbatasan memperoleh pendapat sementara anggaran belanja dan pembiayaan terus meningkat oleh karena itu diperlukan acuan dalam menetapkan arah kebijakan tersebut.

KUA Provinsi Sulut tahun 2018 berisi kebijakan bidang pendapatan, belanja, dan pembiayaan. Kebijakan ini akan menjadi pedoman dalam penyusunan PPAS yang berisi batas atau patokan anggaran yang akan diberikan dalam membiayai program dan kegiatan. Berdasarkan pelaksanaan pembangunan sebelumnya pemerintah mempercepat pembangunan daerah salah satunya dengan menjalankan program prioritas Operasi Daerah Selesaikan Kemiskinan (ODSK). Pemerintah juga mendorong pembangunan berupa sarana dan prasarana untuk menunjang pelayanan public. Prioritas pembangunan Sulut tahun 2018 terdiri dari sepuluh prioritas dan lebih dari seratus program prioritas.

\section{TINJAUAN PUSTAKA}

Anggaran. Menurut Gomes (1995), anggaran berkaitan erat dengan prioritas program dengan sumber pendapatan. Anggaran dibutuhkan untuk mengarahkan pembangunan 
ekonomi daerah, dalam hal ini anggaran sektor publik sangat berperan dalam meningkatkan pelayanan publik dan untuk mewujudkannya pemerintah berupaya membuat program dan kegiatan yang selaras dengan kebutuhan daerah dengan tetap melihat kondisi makro daerah dan asumsi yang mendasarinya. Dengan disusunnya dokumen perencanaan anggaran ini pemerintah berharap program-program prioritas daerah dapat terlaksana dan berjalan sesuai target yang telah ditetapkan.

KUA. Berdasarkan Permendagri Nomor 21 Tahun 2011 Kebijakan Umum Anggaran memuat dokumen rancangan: (1) kebijakan pendapatan; (2) belanja; dan (3) pembiayaan selama satu tahun.

PPAS. Rancangan prioritas plafon anggaran sementara mencakup berbagai urusan wajib maupun pilihan serta plafon anggaran untuk setiap program. Penganggaran harus berjalan efektif dan efisien dengan mengurangi pembebanan pendanaan dengan cara mengoptimalkan program kegiatan yang bukan menjadi prioritas. Proses penyusunan anggaran membahas mengenai prioritas dan sasaran apa yang akan dicapai pada tahun tersebut. Dokumen PPAS menggambarkan pagu anggaran untuk setiap perangkat daerah berdasarkan program yang dituangkan kedalam RKPD.

APBD. Menurut Mardiasmo (2004), yaitu sebagai alat perencanaan, pengawasan, kebijakan fiskal, dan penilaian kinerja. Berdasarkan Undang-Undang Nomor 23 Tahun 2014 APBD merupakan alur dari pengolaan keuangan daerah selama satu tahun. Akuntabilitas dalam penggunaan anggaran daerah dituntut adanya pertanggungjawaban kepada DPRD sekaligus penilaian kinerja pemerintah.

\section{METODE DAN TEKNIK PENERAPAN IPTEKS}

\subsection{Metode Penerapan Ipteks}

Metode penerapan yang digunakan berdasarkan ketentuan umum Permendagri Nomor

21 Tahun 2011 tentang Pedoman Pengelolaan Keuangan Daerah.

\subsection{Teknik Penerapan Ipteks}

Teknik untuk menyusun KUA Provinsi Sulawesi Utara Tahun 2018 yaitu Berdasarkan Permendagri Nomor 21 Tahun 2011 dengan memuat kebijakan bidang pendapatan, belanja dan pembiayaan daerah.

\section{4.. PEMBAHASAN}

\subsection{Gambaran Objek Penerapan Ipteks}

Badan Perencanaan Pembangunan Daerah Provinsi Sulawesi Utara berada dikawasan perkantoran tepatnya di jalan 17 Agustus No. 73 Teling Atas. Bappeda merupakan lembaga daerah yang mempunyai tupoksi dibidang penelitian dan perencanaan pembangunan daerah. Berdasarkan KepPres Nomor 15 Tahun 1974 Bappeda mempunyai tugas Menyusun rencanarencana pembangunan daerah seperti penyusunan dokumen RPJPD, RPJMD, RKPD, menyusun rencana anggaran daerah dengan direktorat keuangan daerah serta mengawasi pelaksanaan dari setiap program dan kegiatan. Saat ini Bappeda mempunyai 109 pegawai termasuk tenaga harian lepas / THL. Untuk mempermudah penyusunan RKPD, dan KUA PPAS Bappeda menggunakan e-planning sebagai alat atau sistem penginputan data.

\subsection{Pembahasan}

Pembahasan dalam dokumen Kebijakan Umum Anggaran (KUA) Provinsi Sulawesi Utara Tahun 2018 terdiri dari tiga unsur kebijakan yaitu :

1. Kebijakan Pendapatan. Untuk dapat meningkatkan pendapatan daerah perlu adannya peningkatan dari berbagai sektor pendapatan seperti pajak, retribusi, dan penerimaan PAD yang sah. Kebijakan dari sumber pendapatan daerah diarahkan untuk dapat meningkatkan jangkauan serta kualitas pelayanan kepada wajib pajak, peningkatan pelayanan pada unit penyedia layanan public, meningkatkan kerjasama antar kabupaten/kota dalam 
meningkatkan penerimaan PAD yang berimplikasi pada bagi hasil pajak daerah. Dengan begitu sumber pendapatan daerah diharapkan meningkat agar pembiayaan pembangunan daerah dapat terlaksana guna membangun atau meningkatkan sarana dan prasaran fasilitas umum.

2. Kebijakan Belanja. Belanja daerah merupakan kewajiban wajib bagi daerah dalam mendanai urusan wajib dan pilihan dalam periode tahun anggaran tertentu. Penggunaan anggaran dapat berjalan efektif dan efisien ketika pemerintah menerapkan money follow program priority dimana program dan kegiatan yang menjadi prioritas utama lebih di kedepankan hal ini akan membuat anggaran berjalan baik dan efisien. Perangkat daerah juga perlu meninjau kembali program yang telah ditargetkan agar anggaran berjalan optimal dan tepat sasaran. Sehingga pagu anggaran juga diharapkan dapat terealisasi sesuai terget yang ditetapkan. Penggunaan anggaran baik belanja tidak langsung atau belanja langsung sebaiknya berjalan berimbang agar tidak terjadi Surplus atau Defisit sehingga porsi anggaran pengeluaran dan pemasukan sama besar.

3. Kebijakan Pembiayaan. Pembiayaan Daerah digunakan untuk membiayai penerimaan yang perlu dibayar atau pengeluaran yang akan diterima kembali baik pada tahun tersebut ataupun tahun berikutnya. Pembiayaan daerah meliputi Penerimaan pembiayaan bersumber dari pinjaman maupun investasi sedangkan pengeluaran pembiayaan digunakan untuk memberi pinjaman dan peyertaan modal kepada pemerintah daerah. Pembiayaan ini juga digunakan untuk pembayaran hutang pokok dan penyertaan modal pemerintah daerah pada Bank SulutGo. Untuk mempertahankan status opini dari BPK dan membuat penyerapan dana dapat berjalan efisien maka diharapkan SILPA cenderung menurun.

\section{KESIMPULAN DAN SARAN}

\subsection{Kesimpulan}

Dalam pelaksanaan dari Kebijakan Umum Anggaran Provinsi Sulawesi Utara Tahun 2018 telah dilakukan sesuai dengan Permendagri Nomor 21 Tahun 2011.

\subsection{Saran}

Perlu adanya upaya dalam meningkatkan pendapatan daerah dan mengoptimalkan pembiayaan agar prioritas seperti pembangunan infrastruktur, pendidikan, kesehatan, penanggulangan kemiskinan dan pengangguran dapat teratasi demi kemajuan Provinsi Sulawesi Utara.

\section{DAFTAR PUSTAKA}

Bastian, Indra. 2006 Sistem Perencanaan dan Penganggaran Pemerintah di Indonesia, Penerbit Salemba Empat. Jakarta

Dokumen Nota Kesepakatan Kebijakan Umum APBD Provinsi Sulawesi Utara Tahun 2018. Manado

Hariadi, Pramono. 2010. Pengelola Keuangan Daerah. Penerbit Salemba Empat. Jakarta

Indonesia. 1974. KepPres Nomor 15 Tahun 1974 tentang Badan Perencanaan Pembangunan Daerah.

Kartika, H.A. 2002. Proses Penyusunan Anggaran Belanja dan Pendapatan Daerah dan Arah Kebijakan Umum. Makalah. Tidak Diterbitkan. Universitas Padjadjaran. Sukabumi

Keputusan Presiden Republik Indonesia Nomor 15 Tahun 1974 tentang Pembentukan Badan Perencanaan Pembangunan Daerah. Jakarta

Keputusan Presiden Republik Indonesia Nomor 27 Tahun 1980 tentang Pembentukan Badan Perencanaan Pembangunan Daerah 
M, Munandar. 2001. Budgeting: Perencanaan, Pengkoordinasian dan Pengawasan Kerja. Universitas Gajah Mada. Yogyakarta.

Mardiasmo. 2004. Akuntansi Sektor Publik. Penerbit Andi. Yogyakarta

Mulyanto. 2008. Tinjauan penyusunan KUA, PPAS dan RKA-SKPD: Beberapa Pokok Pemikiran Awal. LGSP

Pemerintah Indonesia. 2011. Permendagri Nomor 21 Tahun 2011 tentang Perubahan atas Permendagri Nomor 13 Tahun 2006 tentang Pedoman Pengelolaan Keuangan Daerah.

Peraturan Menteri Dalam Negeri Nomor 33 Tahun 2017 tentang Pedoman Penyusunan Anggaran Pendapatan dan Belanja Daerah Tahun 2018

Peraturan Pemerintah Republik Indonesia Nomor 17 Tahun 2017 tentang Sinkronisasi Proses Perencanaan dan Penganggaran. Jakarta

Undang-Undang Nomor 25 Tahun 2004 tentang Sistem Perencanaan Pembangunan Nasional Undang-Undang Republik Indonesia Nomor 23 Tahun 2014 tentang Pemerintahan Daerah. Jakarta 